УДК: 75.03

ББК: 85.143

A43

DOI: $10.18688 / \mathrm{aa} 200-2-19$

E. A. Skvortcova

\title{
Portrait of the Empress Elizaveta Petrovna by Georg Kaspar von Prenner (1754, State Tretyakov gallery) and European Tradition of Portraits in Flower Wreath ${ }^{1}$
}

Georg Kaspar von Prenner, an Austrian painter active in Russia in 1750-1755, is among those artists of Rossica whose works, though broadly known, are so far insufficiently studied. There are only very short introductory entries on him in $18^{\text {th }}-$ beginning of the $20^{\text {th }}$ century dictionaries [15, p. 1163-1164; 45, pp. 378-379; 40, p. 428], some do not mention his stay in Russia at all [31, p. 43]. The most comprehensive biography of him as well as the list of his works is provided by J. H. M. Ernesti and F. C. G. Hirsching (1806) [9, pp. 71-82]. However, his Russian period is only very briefly described by them. N. N. Vrangel, A. N. Benois, E. Gollerbach, providing only concise information about the artist, mention a group portrait by Prenner, in which he, according to Benois, depicted himself portraying Ekaterina, then Grand Duchess, with her son Pavel [49, p. 38; 6, p. 15; 17, p. 26]. In "Russian Academic Artistic School in the $18^{\text {th }}$ Century" edited by S. P. Iaremich the models are identified as Anna Leopol'dovna with Ioann Antonovich and the artist depicted and creator of the painting as Louis Caravaque (1934) [50, p. 15], the attribution was preserved in a recent publication by I. Artemieva (1998) [3, p. 98 $]^{2}$.

The research study of Prenner was for the first time undertaken by V. Makarov (1929). In his brochure an overview of Prenner's biography, not fully comprehensive, but still detailed, is complemented by description of his works from Gatchina palace-museum which then possessed the largest collection of his portraits (7 art works). Makarov severely criticizes the style of the artist: "a master deprived of a school, he adopted just a couple of composi-

\footnotetext{
This research was supported by the grant of the President of the Russian Federation for the young PhDs no. MK-1510.2019.6 "Female and Children Images in Discourse of Imperial Power: On the Example of $18^{\text {th }}$-Century Russian Art” . Статья подготовлена по Гранту Президента РФ для молодых кандидатов наук МК-1510.2019.6 по теме «Женские и детские образы в дискурсе имперской власти: на примере искусства России XVIII века».

2 P. Iu. Novbari doubts an attribution of the painting to Caravaque [33, p. 141]. Such attribution and identification of models is also challenged by the so far ignored fact that F. C. G. Hirshing and J. H. M. Ernesti (1806) mentioned Prenner's portrait in which he depicted himself painting Empress Elizaveta, and another portrait of him, in which he depicted himself painting a self-portrait, both " 5 Schuh hoch, 7 Schuch breit" (approximately $150 \times 210 \mathrm{~cm}$ ) and both highly esteemed [9, p. 79].
} 
tional devices, he was an incapable draughtsman who used color badly" [23, p. 22 $]^{3}$. Later N. L. Rykova (1982) gave a better-reasoned estimate of his manner. She admits that his drawing is rarely irreproachable but notes that, to his credit, he had a decorative flair [37, pp. 16-18]. Although her observations on his "representative baroque style" and "rococo graciousness of gestures" are right, her endeavors to reveal the sources of his stylistics are confined to rather superficial statements about "artistry of French-Italian school" and "pedantry" of the German one. As very little data is available on the artist, especially valuable are archival findings by S. O. Androsov which disclose circumstances of Prenner's enrollment to Russian service and his work in St. Petersburg [2]. Known facts about his works are summarized in museum catalogues [16, pp. 138-139; 32, p. 498; 1, pp. 196-197]. Some attempts to define their peculiar features were made in articles in exhibition catalogues of the last decade "Elizaveta Petrovna and Moscow" [48, p. 85], "Flowers Remnats of Paradise on Earth" [25, pp. 41-44]. Though Prenner's stay in Russia was short and presumably he did not meet the expectations, he certainly deserves closer attention at least because he was a court portraitist of Empress Elizaveta Petrovna.

Prenner's activity in Vienna and Rome before his coming to Russia and after his departure from it remains thus far almost absolutely obscure either. The only album of his works "I taccuini di Georg Kaspar Prenner nel Museo Civico di Treviglio e altri disegni del lascito 'Dell'Era" (1999) - has obvious mistakes concerning Russian material. Under no. 419 the catalogue features a drawing described as a portrait of Catherine the Great (the authors claim that it corresponds to her iconography (in fact such an assertion is far from being true) or Elizabeth (on the ground that the group of drawings in question was in all probability created before Catherine's ascension to the throne and it was during Elizabeth's reign that Prenner worked in Russia). The authors support their reasoning with the argument that she wears the order of St. George "typical for the portraits of Russian Emperors" [13, p. 178]. Established by Catherine the Great, had it been depicted, it should have been the undeniable argument for the drawing's not being a portrait of Elisabeth. However, actually in the portrait we see not the Order of St. George, but the Order of St. Andrew. Moreover the portrait is similar to the mosaic by an Italian master A. Cocchi after L. Caravaque's original which was delivered to Petersburg by Prenner who arrived from Rome [41, p. 60]. The story of its commission and delivery to Russia were examined by S. O. Androsov [2, pp. 249-251]. P. Iu. Novbari in his unpublished graduation paper on Caravaque (2000) which is the first and up to the present day the only attempt to create a full catalogue of artist's heritage, asserted that Cocchi's mosaic is presumably "the only consciously made replica of the lost or hitherto not found original portrait by Caravaque painted before 1746 ". The original was in all probability one of the portraits made in Caravaque's workshop to be sent to European diplomatic missions, including the one in Vatican [33, pp. 143-144]. Important facts about the creation of the series were later revealed by L. A. Markina on the basis of archival data discovered [26, pp. 143-145]. Prenner's sketch drawn, I assume, from mosaic (it is unknown whether he saw the original, but he surely saw the mosaic) reveals an echo of that portrait image. 
Whereas in this case bringing together and comparing portraits from Italian and Russian collections contributes to revealing concrete details (identification of model), sometimes consolidating of Russian and European material enables to recreate context and to speak about work of art's belonging to certain tradition. Thus, insufficiently studied is European context necessary for understanding of Prenner's portrait of Elisabeth dating from 1754 (State Tretyakov gallery, Ill. 12) which was described by A. V. Lebedev (1928) as "a big curious portrait in flower frame" which can serve as "a splendid poster of the epoch of Elizabeth" [22, p. 20]. L. A. Markina points out "complimentary symbolism" of flowers and European tradition of depicting Madonna in floral wreath (2006) [27]. The authors of an exhibition catalogue "Dragotsennaia oprava. Kartina i rama. Dialogi" (2014) argue that this is a conventional motif of the German school of painting but without specifying in which genres it is used and without mentioning the historical link of German lands with Holland while in actual fact the motif was borrowed from Dutch art [11, pp. 142-143]. Markina envisioned a hypothesis that the floral-garland frame could have been painted not by Prenner, but by some other artist, perhaps Louis Caravaque [25, pp. 41-42]. European secular portraits in such frames were reproduced in European publications, but never collected all together and analyzed as a certain type. They are mentioned in works on portraits and portraitists or artists who cooperated with them and were responsible for painting floral frames. The last ones were usually Flemish or Dutch masters specializing in flower painting. However, if depictions of Madonna or saints in flower wreath were very widespread, examples of such secular portraits were not so common. Thus, only three portraits of this type are reproduced in a sustentative catalogue of exhibition of Flemish still-life of the mid- $16^{\text {th }}-17^{\text {th }}$ centuries held at Kunsthistorisches museum, Vienna, in 2002 [5, p. 44, 338, 342]. The present paper is aimed at overview of European secular portraits surrounded with flower wreaths of the end of the $16^{\text {th }}$-first half of the $18^{\text {th }}$ century. The task is justified by the relative rarity of such a type of a portrait. Moreover, literature, in which they are reproduced is for the most part absent from Russian libraries. In connection with the portrait of Elizaveta Petrovna European counterparts were never mentioned.

One of the earliest artworks of that kind is "Portrait of Archduke Ferdinand II" (unknown German artist, c. 1575, oil on canvas, 122,5×93, Kunsthistorisches Museum, Vienna, Ill. 14). In the half-length portrait the second son of Emperor Ferdinand I Habsburg from Anna Jagellonica (Anna of Bohemia and Hungary) who was born in 1529 and took possession of Tirol and other Further Austria in 1564 is represented as a man endowed with extraordinary force and sturdiness. His mature age - when man is still full of vigor and vitality, but already enriched with experience and wisdom - is accentuated in treatment of face with solidly depicted wrinkles. In his hand he holds a hub of Hercules who was one of the principal characters of Habsburg Imperial mythology. His head is crowned with a laurel wreath; on his breast is the Order of the Golden Fleece. In the background we see a column indispensable for a formal portrait and a dramatic landscape with swirling clouds. The artist introduces a motif of a complicated double frame. The portrait is surrounded with flower wreath entwined with the ribbon of the Order and inserted into the mounting adorned with architectural elements. The unusual portrait became one of the emblems of the recent exhibition dedicated to Ferdinand II in Ambras Castle in Innsbruck which was a residential city during his reign. Although the catalogue does not offer special analysis of the portrait, a concise comment 
highlights "propagandistic" meaning of flowers [18, p. 108]. This is not the only example when flower frame surrounds a portrait of a man. There is no contradiction here, as flowers point to monarch's virtues and prosperity of the country. However, we will never come across another such a manly image in such type of a portrait ${ }^{4}$. The treatment of a wreath would also remain unique: tightly woven flowers form a compact strip. Fastened into a strictly geometrical oval frame, bright, but demonstrating limited number of tints, they do not blend with whimsical, but monochrome forms of the landscape background of the portrait. Later, artists would normally avoid landscape background in portraits in flower frames in order not to overburden a composition already replete with forms and colours.

The variety of forms in which flowers can enter composition of a portrait and their meaning would remain beyond the article as they deserve special examination. However, in connection with the Imperial allegories I can not but mention Giuseppe Archimboldos "Portrait of Rudolph II as Vertumnis" (1591, oil on canvas, 68×56, Skokloster castle, Sweden) which embodies the climax of the type of iconography invented by the artist to glorify the Emperor in his earlier versions of "The Seasons" and "The Elements". Flowers and fruits of all the seasons from which the portrait of Rudolf II is composed suggest his identification with the God of Seasons and also, implicitly, the God of Elements. Blooming in accord with each other, they symbolize not only peace, plentitude and harmony of his reign, but also eternal spring of the new Golden age which is to start under his scepter [20]. It is an abundance and diversity of plants put together notwithstanding circulation of the seasons that likens the motif of floral wreath with these allegories.

In the $17^{\text {th }}$ century the development of portraits in flower wreaths is connected primarily with Flemish and Dutch schools. It became the epitome of baroque predilection to sumptuousness and flamboyance. A motif is derived from depictions of Madonna and saints surrounded with garlands which imitated natural flowers used to adorn religious images on feast days [39, pp. 80-81]. This type of iconography emerged in creative atmosphere of Pieter Paul Rubens's circle, at the source of it was Jan Brueghel the Elder [29, p. 2]. Its spread was determined by longing for inculcation of religious veneration with the help of artistic images as well as for revival of reverence for Madonna images after iconoclastic outbursts [14, pp. 123125]. Special importance was attached to this task after the Council of Trent in 1545-1563 [39, pp. 80-81]. On the other hand, forming of the motif of flower garland coincided with burgeoning of the genre of still life and independent flower piece coming into a full existence of its own $[14$, p. 121].

One of the distinguished masters representing this genre both in the art of Holland and Flanders was Jan Davidsz. de Heem (1606-1684) active in Utrecht, Leiden and Antwerp. Apropos of the portrait of William, Prince of Orange, would be King William III of England, cartouche to which was created by Jan Davidsz. de Heem (Ill. 15), his contemporary artist and biographer Arnold Houbraken tells the following story. A wealthy artist and businessman Jan van der Meer van Utrecht commissioned de Heem a painted flower frame and paid him the

$4 \quad$ But the very combination of flowers and military theme became quite usual for baroque culture which can be eloquently exemplified by depictions of "Марс во оружии и цветах" ("Mars surrounded with arms and flowers") in decoration of Russian triumphal arches of the first half of the $18^{\text {th }}$ century [46, pp. 232, 255]. 
incredible fee of 2000 guilder. In 1672 French soldiers looted his property. To recover from loss, van der Meer presented stadtholder William of Orange ruling since 1672, in order to gain his favour, this frame after inserting into it his portrait at the age of 10 . This was a replica of William's likeness painted in 1661 by Court artist Abraham von Raguineau, made either by de Meer on his own or another artist. Symbolism of the portrait - eagles with cornucopias, flanking the portrait, fruits and orange flowers, lion with an orange branch and lilies - made researchers doubt that the composition was not initially painted for the portrait of stadtholder. S. Segal maintains that lion is used as a heraldic lion of the House of Nassau, eagle as a traditional attribute of a ruler, white and red rose stand symbolically for House of Lankaster and the House of York from which originated William's mother Mary Henrietta Stuart, lily embodies purity and virtue [5, pp. 44-45]. P. Taylor defines the meaning of the latter in a more specific way - as a symbol of purity of thoughts and justice. White lily symbolizes faultless moral qualities of the stadtholder, orange one is a reference to the name of the dynasty [44, p. 62].

Different explanations do not necessarily imply that one of the versions is either erroneous or superficial. Taylor convincingly proves that spectator was given certain freedom of interpretation. This or that meaning was attached to particular flowers. The assumption that the whole bouquet should have been deciphered as a cohesive essay in which each element has certain sense, is not verified by the period treatises on art. Moreover some kinds of plants which often figure in flower painting are absent from emblem books [44, p. 55].

Among Flemish masters of still-life who paid tribute to flower garlands was Gaspar Peeter Verbruggen the Younger (1664-1730). His painted frames to paired portraits of Philip V of Spain (Ill. 18) and his wife Maria Luisa of Savoy (Ill. 19) combine depictions of sculptures presented so as if they are supporting the portraits and luxurious flowers scattered in a picturesque composition. There is a portrait of King William III of England attributed to the circle of Verbruggen ${ }^{5}$. In it a wreath framing a portrait of the king is accompanied with freely arranged flowers.

Flower garland soon became one of the favorite motives and was widely used as a frame for religious still lifes, mythological scenes and sometimes even landscapes. It enjoys special popularity in portraiture and not only in portraits of rulers which imply sacred aura, but also in portraits of nobility. There are such unidentified paired portraits of a man and a woman in Mauritshuis, Hague, attributed to Jean Baptiste Morel (both oil on panel, $37.3 \times 28.8$ ), portrait of a man by Daniel Seghers and Gonzales Coques in Koninklijk Museum voor Schone Kunsten, Antwerpen (c. 1670, oil, canvas, $83 \times 59)^{6}$, portrait of a man attributed to Bartolomeo Bimbi and a circle of Jacob Ferdinand Voet (oil, canvas, 130.3×98.8, Vaduz Castle, Liechtenstein, Lot 152 at Christie's, April 1, 2008)7.

An alternative form of the motif is a frame of fruits with inclusion of flowers as in a portrait of two children from Národní galerie, Prague (Joris van Son, Erasmus Quellinus the Younger, 1657, oil on canvas, $70 \times 54$ ), in which Christian symbolism of fruits is combined

Available at: http://www.artnet.com/artists/gaspar-pieter-verbruggen-the-younger/portrait-of-kingwilliam-iii-surrounded-by-ZxSK5g1k17Rhme2jyYvVdw2

$6 \quad$ Available at: https://rkd.nl/nl/explore/images/196898

Available at: https://www.invaluable.com/auction-lot/a-portrait-of-a-gentleman-surrounded-by-agarland-ghfeqhtb4c 
with metaphors of up-bringing [5, p. 342] or in a portrait of a lady (Madame Grignon, daughter of the Marquis de Sevigny?) attributed to the circle of Charles Beabrun in an oval frame surrounded by a garland of fruit, oil on canvas, $69,8 \times 56,5)^{8}$. A remarkable example of a new attitude to a motif of flower frame which emerged in the late period of its development and is characterized by addiction to experiments is "Self-portrait" by Nicola van Houbraken (1720, oil on canvas. 136×99, Uffizi, Florence) - an artist, active in Messina, grandson of a Flemish artist Giovanni Houbraken who settled in this city [28, pp. 32, 88]. In the foreground we see an opulent bouquet, from behind it appears artist's face. So, there are two elements conveyed in an eye-deceiving way: first, a wreath, which always tends to tromp loel painting in its accuracy of reproducing nature, and second, a hole in the canvas. Together they make an effect of double optical illusion provoking to contemplate on mimetic nature of fine arts. There are other rather unusual examples when a motif of flower frame is surprisingly relegated to low culture - for instance, images of musicians (Neapolitan School, $17^{\text {th }}$ century, oil on canvas, $100 \times 74$, Sotheby's, 4 December 2008, Lot 269)9.

In the last quarter of the $17^{\text {th }}$ century a motif of flower garland appeared in the art of the Margraviate of Brandenburg. There Dutch influence on art was predetermined by the policy of patronizing migrants started by Frederick William's Edict of Potsdam in 1685 in order to increase the population of the region devastated by the Thirty Years' War. The Elector's personal taste also played a role in this process. Frederick William spent 4 years in Holland in his youth. One of his favorite artists was an Antwerp master Daniel Seghers - a member of The Society of Jesus and a pupil of Jan Brueghel who introduced the motif of flower garland frames in art. His flower cartouches were greatly admired and overshadowed the very portraits which they framed, so that sometimes artists who created a portrait remains unidentified, but we know that it was Brueghel who made a cartouche. His compositions are more intricate in comparison than those of his teacher: there are not simply flowers, but depiction of a rich sculptural frame embellished with flowers. There are three examples of his flower frames surrounding secular portraits: "A Portrait of a Woman" from Kunsthistorisches Museum, Vienna (c. 1650, oil, canvas, $76,5 \times 58$ ), "Portrait of Archduke Leopold Wilhelm" (together with Jan van den Hoecke, Galleria degli Uffizi, Florence) [24, pp. 33-34], portrait of Nicolas Poussin with whom Seghers collaborated (c. 1650-1651, oil, canvas, 98×79.8, Muzeum Narodowe w Warszawie, Ill. 21). Formerly to him was attributed a portrait of Rubens (now considered to be a work by Christian Luyckx; oil, panel, 98.7×73.4, Princeton University Art Museum) [29] with whom the artist was befriended. It is interpreted by J. R. Martin as a posthumous portrait in which symbolism of flowers and insects is evocative of inevitability of death and hope for resurrection [29, pp. 17-19]. In all abovementioned portraits, except for female one, the model is represented in form of a sculptural bust - such a variation was typical for images of Madonna in flower wreath as well (for example: Erasmus I, Daniel Seghers. Education of the Virgin. C. 1645, oil on canvas, Worcester Art Museum, USA).

Daniel Seghers's pupil Ottomar Elliger the Elder from Gothenburg was enrolled to the ser-

\footnotetext{
8 Available at: http://www.artnet.com/artists/charles-beaubrun/portrait-of-a-lady-madame-grignondaughter-of-the-9xUNQhlRR91t7CUrZFk8vg2

9 Available at: www.sothebys.com/en/auctions/ecatalogue/2008/old-master-paintings-day-sale-108037/ lot.269.html?locale $=$ en
} 
vice to Brandenbrug in 1670 . He was a forefather of a dynasty of artists, one offspring of which would later come to Russian service. Ottomar Elliger painted a portrait of Kurfürstin Dorothea (c. 1670/1675, Caputh Castle, Schwielowsee, Berlin-Brandenburg, Ill. 17), the second wife of Frederick William I. In a full-length portrait of the Kurfürstin in ceremonial clothes with an ermine-trimmed mantle upon the background of classical architecture everything corresponds to canons of formal portraiture, but not the size. A depiction of the Kurfürstin appears tiny in comparison with a painted frame rich in spring and summer flowers and fruits. R. G. Scharmann claims that the portrait should have promoted her image of a caring mother of the country [38, pp. 13-14]. Another sample of a portrait dominated by a flower garland is "Portrait of an Officer" attributed to Catharina Ykens (? oil on canvas, 104.4×78.8) ${ }^{10}$ in which a traditional representational depiction of a man in armory upon landscape background is turned into a miniature.

For some time from 1660 at the service of "the Great Elector" was a Dutch master Adriaen van der Spelt. He created a flower frame for the portrait of Karl Aemil, Kurprinz of Brandenburg, Frederick William's son from his first wife Louise Henrietta of Nassau (Ill. 16). The very portrait was made by another master, also presumably of Dutch origin [7, pp. 34-36]. It is a full-body depiction of a boy in Roman armory and ermine-trimmed mantle, which he is lifting in a gesture full of elegant confidence. His arms and scepter are painted in trompl'oeil technique and shown so as if they come out of the canvas - a device usual for portraits in flower frames which by their very nature invite optical effects (compare with "Portrait of Archduke Ferdinand II").

Soon a spectacular motif entered French art. Versailles features such a portrait of MarieAnne de Bourbon, lère Mademoiselle de Blois, princesse de Conti, daughter of Louis XIV from his mistress Louise de La Vallière ${ }^{11}$. Neither a portraitist nor an artist who contributed a flower frame are identified. The composition with flowers densely filling space around a portrait is firmly rooted in the old traditions. Among flowers are a conventional sunflower and lilies. But tulips, which customarily used to prevail, are partly replaced by roses. Vibrant colors of Dutch and Flemish masters give way to modulated yellowish and pinkish tones enlivened by accents of red.

French art gave birth to a new type of composition - a portrait in a portrait. In a canvas we see a portrait depicted which is surrounded with a garland of natural flowers and supported by a servant or some other secondary character. This type can be illustrated by "Portrait of Philippe de France, Duke d'Orléans and His Daughter Marie Louise de Bourbon" (School of Pierre Mignard, last quarter of the $17^{\text {th }}$ century, oil on canvas, $148 \times 177$, Versailles). A portrait of a girl framed by natural flowers bringing out her freshness and beauty is held by a dreamy cupid, next to him stands the proud father ${ }^{12}$.

10 Available at: https://www.christies.com/lotfinder/paintings/attributed-to-catharina-ykens-portrait-ofan-5622907-details.aspx

${ }_{11}$ Available at: http://collections.chateauversailles.fr/\#43e66982-82f4-4cc4-ba6f-e2f9ba94f66b http:// www2.culture.gouv.fr/public/mistral/joconde_fr?ACTION=CHERCHER\&FIELD_1=REF\&VALUE_1=000 PE012176 https://www.photo.rmn.fr/archive/13-540389-2C6NU05DNC5B.html

12 Available at: http://www2.culture.gouv.fr/public/mistral/joconde_fr?ACTION=RETROUVER\&FI ELD_98=TOUT\&VALUE_98=Philippe\%20de\%20France\&NUMBER=20\&GRP=0\&REQ=\%28\%28Philip 
Another variation of such a compositional type is found in Nicolas de Largillière's and JeanBaptiste Belin de Fontenay's "Portrait of Hélène Lambert de Thorigny" (c. 1696-1700?, oil on canvas, $160 \times 114,3$, Honolulu Museum of Arts, Ill. 21), a wife of a wealthy Norman financier. Exquisite dress, architectural background and a drapery, the presence of an Arabic boy are to stress high social status of the model. At the same time the portrait demonstrates rococo lightness, gallantry and coquetry which are revealed not only in utmost graciousness of Madame de Thorigny's posture as well as in a motif of admiration appearing in a figure of a servant, but also in the very concept of a painting built on a subtle game with a spectator. A model is represented in a conventional flower wreath. But this is not a simple flower frame. Nor is it simply a portrait in a portrait. Madame de Thorigny appears as a real figure who is approaching a real flower wreath, flirtatiously estimating whether such a frame passes her and putting the last flower into a gorgeous composition. Arabic boy's figure is painted in trompe-loel technique. The portrait must have been liked as there is a similar portrait of an unknown lady (Jean-Baptiste Belin de Fontenay. Portrait of a Lady. $17^{\text {th }}$ century. Musee des Beaux-Arts, Caen). In French portraits the motif lost sacramental meaning originally inherent to it in Flemish and Dutch art, its new function was to be a fashionable accessory accentuating model's attractiveness.

Fondness for flower wreaths was at its peak in the $17^{\text {th }}$ century. In the $18^{\text {th }}$ century flowerframed paintings of the preceding centuries were highly valued, but the motif was no more so popular in contemporary painting. A rare sample dating from this time is a portrait of Maria Theresa's eldest son future Holy Roman Emperor Joseph II as a child (c. 1745, oil on canvas, $62,5 \times 79,1$, National Trust, Wimpole, Cambridgeshire, inv. NT 207833) ${ }^{13}$. Such late use of the motif in Habsburgs art can be partly elucidated by penchant for flower painting revealed in picture gallery of Holy Roman Emperor Karl VI in Vienna. There was a special room housing exclusively fruit and flower still-lifes and religious scenes and secular portraits in flower frames. Such a hanging was devised by architect Claude Lefort du Plessy who was responsible for re-decoration of upper-floor interiors in Stallburg, above the stables (the former Rüstkammer) for a picture [43, p. 102]. Baroque ensemble based on coloristic harmony and symmetry was to produce a primarily decorative effect. If other genres focused on meaning rather than form resisted this principle, flower room as depicted in gouaches of Ferdinand Storffer's "Inventar" (1730, Ill. 13) became apotheosis of decorativeness [19, p. 8]. It also visualized the idea of succession. Painted plafond by Theodor van Thulden "The Return of Peace" was to remind of the deeds of Karl VI's uncle archduke Karl Wilhelm, stadtholder of Spanish Netherlands. Under his reign Stallburg started to house an artistic collection. And a special penchant had he for flower and fruit stilllifes. There are 135 such paintings in inventory of 1659. To represent his status of an Emperor higher than that of archduke Karl Wilhelm, Karl VI increased his collections by new purchases and transferring to Stallburg some part of the collections from Prague and Innsbruck. Flower room was Karl VI's homage to his predecessor [42, p. 20]. No doubt during his stay in Vienna Georg Prenner visited Karl VI's gallery. It was open for pubic, though for relatively high fee [42, p. 12]. Furthermore, Georg Prenner assisted his uncle and teacher Anton Prenner in making en-

pe $\% 20 \mathrm{de} \% 20 \mathrm{France} \% 29 \% 20 \% 3 \mathrm{aTOUT} \% 20 \% 29 \&$ USRNAME=nobody $\& U S R P W D=4 \% 24 \% 2534 \mathrm{P} \&$ SPEC= $5 \& S Y N=1 \& I M L Y=\& M A X 1=1 \& M A X 2=1 \&$ MAX $3=200 \& D O M=$ All

13 Available at: http://www.nationaltrustcollections.org.uk/object/207833 
gravings for a gallery's catalogue which was published under the name "Prodromus" $(1735)^{14}[9$, p. 73]. Although this evidence is not enough to prove that flower frame of "Portrait of Empress Elizaveta Petrovna" was painted by Prenner and not by some other artist, it reinforces this point and makes us deduce that the concept of a portrait was coined by him.

A motif of a flower garland surrounding a portrait did existed not only in easel painting, but also in other kinds of art, such as monumental painting, sculpture, porcelain. In Russian art of the time of Empress Elizaveta this can be exemplified by a painted plafond "Triumph of Bacchus and Ariadna" in the $5^{\text {th }}$ Antechamber of the Great Tsarskoe Selo Palace (after Pietro and Francesco Gradizzi's sketches) in which a monogram of the Empress (which has the same meaning as a portrait) is surrounded with a rose wreath. To a later period belongs modelled decoration of the Throne hall of the Great Peterhof Palace in which sculpted garlands encircle painted portraits of the members of the tsar's family (1777-1778, after G. F. Veldten's project). A curious example dating from the first half of the $19^{\text {th }}$ century are decorative Meissen cups adorned with painted portraits of Peter the Great and Catherine the Great surrounded with colored modelled garlands of flowers [8, p. 28]. In these cases flower frame is nothing but a conventional element of decoration akin to the flower garland. In Russian easel painting Prenner's portrait seems to be almost the only existing example. A rare sample in which a similar motif can be found is David Lüders's group "Portrait of Envoy P. G. Chernyshev with His Family" (1750, oil, canvas, $218 \times 296.5$, State Hermitage, Saint-Petersburg, ЭРЖ-2930) ${ }^{15}$ in which one of Envoy's daughters is decorating a portrait of a boy with a garland of flowers. In the $19^{\text {th }}$ century the motif seems to preserve only decorative role deprived of specific symbolic meaning as, for instance, in an engraved portrait of Nicolai I, his wife Aleksandra and their son Aleksandr, a heir for the throne (reproduced in: [21, p. 23]).

In European context "Portrait of Empress Elizaveta Petrovna" painted in the middle of the $18^{\text {th }}$ century is an anachronism. Unlike most portraits of such type it is very large $204,5 \times 158,5 \mathrm{~cm}$. Relation of a portrait image and a frame is accurately balanced, so that the wreath underlines the importance of a model, but does not overshadow her - this is not typical, but not unique either. It is an indeed lavish display of flowers - extraordinarily, but not uniquely rich. What makes this portrait the only one of its kind is a combination of exclusively sumptuous frame and significance of a portrait image - a faultless artistic decision which transmits state and international status of a model ${ }^{16}$.

\footnotetext{
14 "Predecessor" (Latin). The work on a full catalogue lingered (it remained unfinished), it was decided to make a shorter version first. Hence the name [42, p. 26].

15 Available at: https://hermitagemuseum.org/wps/portal/hermitage/digital-collection/01.\%20 Paintings/153832/!ut/p/z1/jZBNT8MwDIb_Cjv0SOKkTVt2i4LEGBudJj5CLqibujSoTao2rBK_noC4gKDMN0 uPXz82VlhiZcuj0aU3zpZN6J9U-lxwnpJYwLIQ7BJ4sd2wrbi9ApLgx08A_igOWJ0yPwGo6fjlfwvCBbRfi7XGqi t9fW7swWEJBJ1tSmO9sXrAkrA4j2mQUT_irm-yEHfHFkXxIKhIvoBpIbNr0bhvESBGGZD4AiDPaJbk6YcNt 7s4DzZ9daj6qkevfXhz7X03zCOIYBxHpJ3TTYX2ro3gt5HaDR7L7yTu2nv5tlrAC2uOKz6bvQOYG2nD/dz/d5/ L2dBISEvZ0FBIS9nQSEh/?lng=ru

16 A telling example of flower frames signifying the position of a ruler on international arena can be found in $17^{\text {th }}$-century Russian art. It is a manuscript "Titulyarnik" (or "Bol'shaia Gosudareva Kniga", or "Koren' Rossijskikh Gosudarei...") created in 1672 in the Posol'skii Prikaz (Ministry of International affairs) as a diplomatic reference book [10]. Richly ornamented with illustrations, it contains 30 portraits of Russian princes and tsars from Riurik to Alexei Mikhailovich 13 portraits of the Ecumenical Patriarchs including Moscow Patriarchs, and 22 portraits of contemporary foreign rulers. Flower frames are highly stylized and
} 
It is still to be proved with the means of technical-technological analysis that flower wreath was painted together with the portrait as hypothetically it might have been brought by Prenner from Europe and the portrait was later fitted into $\mathrm{it}^{17}$. The reasons to assume that are the practice of creating empty frames by a specialist flower painter for portraits to be fitted into them, on the one hand, and the existence of a similar portrait of Elizaveta without a frame, on the other [32, p. 498; 12, p. 3]. However, the disposition of flowers makes such a supposition highly unlikely. Sunflower is traditionally placed at the top of a composition. L. A. Markina noted that passiflora resembling the star of the Order of St. Andrew on the breast of the Empress is depicted next to it [25, p. 44]. The flower of Fritillaria, or Corona Imperialis, is positioned beside the Orb, the symbol of monarch's power, whereas the enigmatic flower of phallic form which remained thus far unidentified and which, I presume, is a banana flower, is painted beside the scepter ${ }^{18}$. Thus, the "program" of flower wreath seems to have been invented specially for the portrait ${ }^{19}$. In "Portrait of Elizaveta Petrovna" political symbolism of flower wreath together with its general sacramental meaning rooted in Flemish and Dutch tradition coexist with an emphasis on beauty of a model which emerged in French painting.

Metaphors of a blooming garden in poetry and fests programs of the time of Elizabeth were examined by S. L. Baehr and J. Pogosjan in context of "paradise myth" as symbols of peaceful prosperity of the Empire [4, pp. 65-67, 74, 86; 36]. K. Ospovat points to the metaphorical motif of "eternal spring" emerging in M. Lomonosov's poetry in relation to Tsarskoe Selo greenhouses which politically revitalized conventional poetical device of glorification of palace parks, including Versailles [34,35]. Prenner's portrait of Empress Elizaveta does not correspond to any of the poetical texts directly and does not originate from them: flower wreath, as is it is proved in the present article, was a traditional motif in painting ${ }^{20}$. But it fitted brilliantly into Imperial symbolism. And its panegyric exultant intonation made it an excellent expression of the spirit of court culture of the time of Elizabeth, when Russia, in the words of M. Kheraskov «как сад веселый разцветала» ("as a merry garden was in bloom”).

have nothing to do with European tradition. But interestingly, relatively simple frames encircling portraits of velikie kniazia give way to a much more luxurious ones starting with a portrait of Ivan IV who was first crowned as a Russian tzar and thus got a higher title.

17 How surprising can be discoveries made as a result of technical examination of paintings in floral garlands show the story of "Garland of Flowers and Vase" by Gaspar Peeter Verbruggen the Younger [47].

18 Importantly, banana flower was among flowers depicted by Sybilla Merian whose botanic atlases were very widespread $[51$, p. 226]. The mismatch of the colors can be explained by the fact that the artist never saw a real flower and painted it from black-and-white engraving. I express my gratitude to Dr. Annika Waenerberg for giving me this idea.

19 I express my gratitude to Dr. L. A. Markina, Dr. E. A. Tiukhmeneva, Dr. I. E. Putiatin for fruitful discussion of this question at Dr. A. A. Aronova seminar "Problems of Artistic Culture of the $18^{\text {th }}$ Century" at State Institute for Art Studies after presentation of my paper (28 February 2019).

20. A case of direct correspondence of such motif to the text is an engraved portrait of Catherine II in a frame of flowers, fruits and leaves with the poetic inscription beneath collating her to the God's rain which gives life to plants (so she gives life to glorious deeds of her subjects generously supporting them) [Available at: https:// goskatalog.ru/portal/\#/collections?id=10158417; Rovinskii D.A. Podrobnyi slovar' russkikh gravirovannykh portretov (Comprehensive Dictionary of Russian Engraved Portraits). Vol. 2. Saint-Petersburg: Academy of Science Publ., 1887. №298]. It was made for N.M. Maksimovich-Ambodik's "Vrachebnoe veshchestvoslovie ili Opisanie tselitel'nykh rastenii vo vrachevstve upotrebliaemykh..." [Description of Medical Plants] (SaintPetersburg, 1783-1789) written by him "po vysochaishemu poveleniiu" (upon Empress's order). 


\section{References}

1. Andreeva G. B.; Markina L. A. Zhivopis' 18 veka. Gosudarstvennaia Tret'akovskaia galereia. Katalog sobraniia (Painting of the $18^{\text {th }}$ Century. State Tretyakov gallery. Catalogue). Moscow, State Tretiakov gallery Publ., 2015. 407 p. (in Russian).

2. Androsov S. O. A Forgotten Russian Maecenas - Count Mikhail Vorontsov. Pamiatniki kul'tury. Novye otkrytiia: Pis'mennost'. Iskustvo. Arkheologiia: Ezhegodnik. 2000. (Monuments of Culture. New Discoveries: Script. Art. Archeology: An Annual. 2000). Moscow, Nauka Publ., 2001, pp. 246-277 (in Russian).

3. Artemieva I.; Pavanello G. Masterpieces from the Hermitage. Brussels, Art media; Milano, Electa Publ., 1998. $167 \mathrm{p}$.

4. Baehr S. L. The Paradise Myth in Eighteenth-Century Russia: Utopian Patterns in Early Secular Russian Literature and Culture. Stanford (Calif.), Stanford University Press Publ., 1991. 308 p.

5. Balis A.; Nitze-Ertz Ch.; Kleinmann U. Das Flämische Stillleben. 1550-1680. Wien, Kunsthistorisches Museum Publ.; Luca, Lingen Publ., 2002. 402 p. (in German).

6. Benois A. N. Exhibition Dedicated to the Time of Empress Elizaveta Petrovna. Starye Gody (Old Years), 1912, May, pp. 3-28 (in Russian).

7. Börsch-Supan H. Die Kunst in Brandenburg-Preußen: ihre Geschichte von der Renaissance bis zum Biedermeier dargestellt am Kunstbesitz der Berliner Schlösser. Berlin, Mann Publ., 1980. 324 p. (in German).

8. Cherezova L. Meisenskii farfor $v$ sobranii Tul'skogo khudozhestvennogo muzeia (Meissen Porcelain in the Collection of Tula Museum of Fine Arts). Tula, Lev Tolstoi Publ., 1994. 32 p. (in Russian).

9. Ernesti J. H. M.; Hirsching F. C. G. Historisch-literarisches Handbuch berühmter und denkwürdiger Personen, welche in dem 18. Jahrhunderts gelebt haben: oder historische, bio- und bibliographische Nachrichten von berühmten Kaisern, Königen, Fürsten, großen Feldherrn, Staatsmännern, Päpsten, Cardinälen, Erz- und Bischöfen, Gelehrten aller Wissenschaften, Baumeistern, Künstlern, Kaufleuten, Mechanikern und andern merkwürdigen Personen beyderley Geschlechts, vol. 8, part 2. Leipzig, Schwickertscher Verlag, 1806. 408 p. (in German).

10. Eskin Iu. M. (ed.). Tsarskii Tituliarnik, 2 vols. Moscow, Stoliarov Foundation Publ., 2007. 244; 194 p. (in Russian).

11. Evseeva E. D. Kartina i rama. Dialogi (A Painting and a Frame. Dialogues). Moscow, State Tretiakov gallery Publ., 2014. 435 p. (in Russian).

12. Fedorov V. (ed.). Catherine the Great: An Enlightened Empress: (Published to Accompany the Exhibition Held at the National Museums Scotland, Edinburgh, 13 July to 21 October 2012: From the Collections of the State Hermitage Museum, St. Petersburg). Edinburgh, NMS Enterprises Publ., 2012. 208 p.

13. Frabbi N. I taccuini di Georg Kaspar Prenner nel Museo Civico di Treviglio e altri disegni del lascito 'Dell'Era'. Bergamo, Bolis Publ, 1999. 250 p. (in Italian).

14. Freedberg D. The Origins and Rise of the Flemish Madonnas in Flower Garlands Decoration and Devotion. Münchner Jahrbuch der bildenden Kunst, 1981, vol. 32, pp. 115-150.

15. Füssli J. R.; Füssli H. H. Allgemeines Künstlerlexikon, oder: Kurze Nachricht von dem Leben und den Werken der Maler, Bildhauer, Baumeister, Kupferstecher, Kunstgiesser, Stahlschneider u.u.; nebst angehängten Verzeichnissen der Lehrmeister und Schüler, auch der Bildnisse, der in diesem Lexikon enthaltenen Künstler, part 2, sec. 5. Zürich, bey Orell, Füßlin und Compagnie Publ., 1810. 1404 p. (in German).

16. Goldovskii Gr. Zhivopis'. 18 vek. Katalog. Gosudarstvennyi Russkii muzei (Painting. The $18^{\text {th }}$ Century. Catalogue of the State Russian museum, vol. 1). St. Petersburg, State Russian museum Publ., 1998. 206 p. (in Russian).

17. Gollerbakh E. F. Portretnaia zhivopis'v Rossii XVIII veka (Portrait Painting in Russia in the $18^{\text {th }}$ Century). Moscow; Petrograd, State Publ., 1923. 139 p. (in Russian).

18. Haag S.; Sandbichler V. Ferdinand II.: 450 Jahre Tiroler Landesfürst: Jubiläumsausstellung. Innsbruck; Wien, Haymon Publ., 2017. 365 p. (in German).

19. Heinz G. Geistliches Blumenbild und dekoratives Stillleben in der Geschichte der kaiserlichen Gemäldessammlungen. Jahrbuch der kunsthistorischen Sammlungen in Wien, 1973, vol. 69 (Neue Folge Bd 33), pp. 7-54 (in German).

20. Kaufmann, Th. DaCosta. Archimboldo's Imperial Allegories. Zeitschrift für Kunstgeschichte, 1976, vol. 39, part 4, pp. 275-296. 
21. Kuspak I. N. Stankovaia grafika (Easel Graphics at the Museum of Fine Arts of Karerlia). Petrozvodsk, Karelia Publ., 2008. 231 p. (in Russian).

22. Lebedev A. V. Russkaia zhivopis'v 18 veke (Russian Painting in the $18^{\text {th }}$ Century). Leningrad, Academy of Material Culture Publ., 1928. 66 p. (in Russian).

23. Makarov V. Georg Gaspar Prenner i ego raboty v Gatchinskom dvortse-muzee Leningrada (Georg Gaspar Prenner and His Works at the Gatchina Palace-Museum in Leningrad). Leningrad, Gatchina PalaceMuseum Publ., 1929. 26 p. (in Russian).

24. Manteuffel K. Z., von. Bilder flämischer Meister in der Galerie der Uffizien zu Florenz. Monatshefte für Kunstwissenschaft, 1921, April, vol. 14, no. 1, pp. 29-49 (in German).

25. Markina L. A. Admirers of Charming Flora. Adaksina N. L.; Aleksandrova N. A. (eds.). Tsvety - ostatki raiia na zemle (Flowers Are Remnats of Paradise on Earth). Moscow, Tritona Publ., 2009, pp. 39-50 (in Russian).

26. Markina L. A. German-Russian Artistic Exchange of the mid- $18^{\text {th }}$ Century - Aspect of Enlightenment Activity. Kul'tura epokhi Prosveshcheniia: sbornik statei (Culture of the Epoch of Enlightenment: Collection of Articles). Moscow, Nauka Publ., 1993, pp. 127-149 (in Russian).

27. Markina L. A. "Happy Star" of a Court Artist in Russia. Russkoe iskusstvo (Russian Art), 2006, no. 3. Available at: http://www.russiskusstvo.ru/themes/theme/a1497/ (accessed 21 May 2019) (in Russian).

28. Martin J.-H. Carambolages. Paris, Réunion des musées nationaux Publ., 2016. 63 p. (in French).

29. Martin J. R. A Portrait of Rubens by Daniel Seghers. Record of the Art Museum, 1958, vol. 17, no. 1, pp. 2-20.

30. Merriam S. Seventeenth-Century Flemish Garland Paintings. Still Life, Vision and the Devotional Image. Farnham; Burlington, VT, Ashgate Publ., 2012. 173 p.

31. Nagler G. K. Neues allgemeines Künstler-Lexicon oder Nachrichten von dem Leben und den Werken der Maler, Bildhauer, Baumeister, Kupferstecher, Formschneider, Lithographen, Zeichner, Medailleure, Elfenbeinarbeiter, etc., vol. 12. München, E. A. Fleischmann Publ., 1842. 556 p. (in German).

32. Nikulin N. N. Nemetskaia i Avstriiskaia zhivopis' 15-18 veka: Katalog (German and Austrian Painting of the $15^{\text {th }}-18^{\text {th }}$ Centuries, catalogue). Leningrad, Iskusstvo Publ., 1987. 541 p. (in Russian).

33. Novbari P. Iu. Katalog proizvedenii Lui Karavaka (1684-1754) (Catalogue of the Works of Louis Caravaque (1684-1754)). 2000. Bibliography Department of Scientific Archive of Russian Academy of Fine Arts, Saint-Petersburg. Fund 11. Inventory 2. Item 5378 (in Russian).

34. Ospovat K.A. Lomonosov and "A Letter about the Benefits of Glass". Novoe literaturnoe obozrenie (New Literary Survey), 2007, no. 5. (in Russian). Available at: https://magazines.gorky.media/nlo/2007/5/ lomonosov-i-pismo-o-polze-stekla-poeziya-i-nauka-pri-dvore-elizavety-petrovny.html (Accessed 12 June 2020).

35. Ospovat K.A. Poetry and Patronage. About One Work of Lomonosov. The Real Life of Pierre Dalelende: Studies in Russian and Comparative Literature to Honor Alexander Dolinin. [Stanford, Calif.], Stanford University, Dept. of Slavic Languages and Literatures, Oakland, Berkeley Slavic Specialties, 2007, pp. 1337. (in Russian).

36. Pogosjan E.A. Garden as a Political Symbol in Lomonosov's Poetry. Kul'tura. Tekst. Narrativ. Trudy po znakovym sistemam - XXIV. (Culture. Text. Narrative. Essays on Sign System). Tartu, Tartu State University Publ., 1992, pp. 50-51 (in Russian).

37. Rykova N. L. Georg Gasper Prenner v Rossii. Russkaia khudozhestvennaia kul'tura 18 veka i inostrannye mastera. Vsesoiuznaia nauchnaia konferentsiia molodykh spetsialistov. Tezisy dokladov (Russian Artistic Cilture of the $18^{\text {th }}$ Century. Abstracts of USSR Conference of Early-Career Scholars). Moscow, s.n., 1982, pp. 16-18 (in Russian).

38. Scharmann R. G. Von Gartenträumen und Rosenkaiserinnen: Blumenkunst und Pflanzensymbolik in preussischen Schlössern. Berlin, Braus Publ., 2016. 120 p.

39. Sladkov V. A. Zrimyi obraz i skrytyi smysl: Allegorii i Emblemy v zhivopisi Flandrii $i$ Gollandii vtoroi poloviny 16-17 veka (Visible Image and Concealed Sense: Allegories and Emblems in Painting of Flanders and Holland of the Second Half of the $16^{\text {th }}-17^{\text {th }}$ Centuries). Moscow, Alfa-Print Publ., 2004. 155 p. (in Russian).

40. Sobko N. P. Slovar' russkikh khudozhnikov, vaiatelei, zhivopistsev, zodchikh, risoval'shchikov, graverov, litografov, medalerov, mozaichistov, ikonopistsev, liteishchikov, chekanshchikov, skanshchikov i proch.: $S$ drevneishikh vremen do nashikh dnei (IX-XIX vv.) (A Dictionary of Russian Artists, Sculptors, Painters, Architects, Draughtesmen, Lithographers, Medal-Makers, Mosaic-Makers, Icon-Painters, 
Molders, etc.: From Ancient Times to the Present Days ( $9^{\text {th }}-19^{\text {th }}$ Centuries)), vol. 3, iss. 1. St. Petersburg, M. M. Stasiulevich Publ., 1899. 508 p. (in Russian).

41. Stolpiianskii P. Staryi Peterburg. Starye Gody (Old Years), 1912, March, pp. 60-63 (in Russian).

42. Swoboda G. Die verdoppelte Galerie. Die Kunstsammlungen Kaiser Karls VI. In der Wiener Stallburg und Ihr Inventar. Haag S.; Swoboda G.; Oberthaler E.; Wald R. Die Galerie Kaiser Karls VI. in Wien: Solimenas Widmungsbild und Storffers Inventar (1720-1733). Wien, Kunsthistorisches Museum Publ., cop. 2010, pp. 11-31 (in German).

43. Swoboda G. Die Wege der Bilder: eine Geschichte der kaiserlichen Gemäldesammlungen von 1600 bis 1800 . Wien, Kunsthistorisches Museum, Brandstätter Publ., 2008. 164 p. (in German).

44. Taylor P. Dutch Flower Painting, 1600-1720. New Haven, London, Yale university press Publ., 1995. $227 \mathrm{p}$.

45. Thieme U.; Becker F. (eds.). Allgemeines Lexikon der bildenden Künstler von der Antike bis zur Gegenwart, vol. 27. Leipzig, W. Engelmann, 1907-1930. 600 p. (in German).

46. Tiukhmeneva E. A. Iskusstvo triumphalnykh vrat $v$ Rossii pervoi poloviny 18 veka: problem panegericheskogo napravleniia (The Art of Triumphal Gates in Russian in the First Half of the $18^{\text {th }}$ Century). Moscow, Progress-Traditsiia Publ., 2005. 327 p. (in Russian).

47. Vandivere A. Changes of Identity in "Garland of Flowers and Vase" by Gaspar Peeter Verbruggen the Younger. Oud Holland, 2009, vol. 122, no. 2/3, pp. 164-180.

48. Vorozhbitova M. V.; Pogodina A. A.; Markina L. A. Elizaveta Petrovna i Moskva (Empress Elizabeth and Moscow, Exhibition Catalogue). Moscow, Art-Volkhonka Publ., 2010. 218 p. (in Russian).

49. Vrangel N. N. Foreign Artists in Russia in the $18^{\text {th }}$ Century. Starye gody (Old Years), 1911, JulySeptember, pp. 5-94 (in Russian).

50. Vrangel N. N. The First Years of the Academic School. Iaremich S. P. (ed.). Russkaia akademicheskaia khudozhestvennaia shkola v XVIII veke. Izvestiia Gosudarstvennoi akademii istorii material'noi kul'tury. Vyp. 123 (Russian Academic Artistic School in the 18 $8^{\text {th }}$ Century. News of the State Academy of the History of Material Culture, vol. 123). Moscow; Leningrad, State Social-Economic Publ., 1934, pp. 11-30 (in Russian).

51. Wettengl K. Maria Sibylla Merian Künstlerin und Naturforscherin: 1647-1717. Ostfildern, Hatje-CantzVerlag Publ., 2013. 275 p. (in German).

Title. Portrait of the Empress Elizaveta Petrovna by Georg Kaspar von Prenner (1754, State Tretyakov Gallery) and European Tradition of Portraits in Flower Wreath

Author. Skvortcova, Ekaterina Aleksandrovna - Ph. D., associate professor. Saint-Petersburg State University, Universitetskaia nab., 7/9, 199034 St. Petersburg, Russian Federation. e.skvortsova@spbu.ru

Abstract. This research was supported by the grant of the President of the Russian Federation for the young PhDs no. MK-1510.2019.6 "Female and Children Images in Discourse of Imperial Power: On the Example of $18^{\text {th }}$-Century Russian Art".

"Portrait of Empress Elizaveta Petrovna" by G. K. von Prenner is the only $18^{\text {th }}$-century secular easel portrait in a painted flower frame in Russian art. "Complimentary symbolism" of flowers was deciphered by L. Markina who also indicated portrait's link to European tradition of depicting Madonna in floral wreath. However, a more important context of European secular portraits surrounded with flower garlands has so far been completely ignored. Neither have these portraits been a subject of special examination in European art history. The paper offers an overview of such European portraits of the last quarter of the $17^{\text {th }}-$ early $18^{\text {th }}$ centuries. Upon their background the portrait of Elizaveta Petrovna demonstrates a unique combination of exclusively sumptuous frame and significance of a portrait image - a faultless artistic decision which transmits state and international status of a model. The portrait preserves sacramental political connotations traditionally inherent to garland painting in Dutch and Flemish art chiming with the ideas manifested in literature of Elizabethan time in which the metaphor of the garden epitomized the idea of peaceful prosperity of the Empire. On the other hand, Prenner's portrait floral frame is also an accessory accentuating beauty of a model as it was in late $17^{\text {th }}$-century French samples. Prenner could have special appreciation of garland frames as he was familiar with the gallery of the Emperor Carl VI in Stallburg in Vienna which had a special room featuring exclusively flower still-lifes and pictures in flower frames (counting some portraits). How actual the motif turned out to be at the court of Empress Elizaveta demonstrates its widespread in other kinds of art (triumphal arches, painted plafonds, molded interior decoration, applied art, engraving).

Keywords: G. K. von Prenner, $18^{\text {th }}$-century Russian art, $17^{\text {th }}-18^{\text {th }}$-century European art, painting, Rossica, secular portrait in flower frame, garland paintings, iconography of Empress Elizaveta Petrovna 
Название статьи. «Портрет Елизаветы Петровны» Г.-К. фон Преннера (1754 г., ГТГ) и европейская традиция портрета в цветочном обрамлении

Сведения об авторе. Скворцова Екатерина Александровна - кандидат искусствоведения, доцент. Санкт-Петербургский государственный университет, Университетская наб., д. 7/9, Санкт-Петербург, Российская Федерация, 199034. e.skvortsova@spbu.ru

Аннотация. Статья подготовлена по Гранту Президента РФ для молодых кандидатов наук МК-1510.2019.6 по теме «Женские и детские образы в дискурсе имперской власти: на примере искусства России XVIII века».

«Портрет императрицы Елизаветы Петровны» Г.-К. фон Преннера - единственный в искусстве России XVIII столетия станковый светский портрет в живописной цветочной раме. Л. А. Маркина расшифровала «комплиментарный символизм» растений и указала на европейскую традицию изображения в цветочном венке Мадонны. Однако не менее существенный контекст светских европейских портретов в цветочных обрамлениях до сих пор оставался за гранью внимания исследователей. Равно как и в европейском искусствознании они по сей день не рассмотрены как особая типологическая линия. В статье предложен обзор подобных портретов последней четверти XVII - начала XVIII в. На их фоне портрет Елизаветы Петровны выделяется уникальным сочетанием исключительной пышности рамы и значимости портретного образа - тонко найденное художественное решение, передающее высокий государственный и международный статус модели. Портрет сохраняет сакраментальные политические коннотации, традиционно свойственные мотиву цветочной гирлянды во фламандской и голландской живописи, обнаруживая созвучие литературе Елизаветинской эпохи, в которой обрела распространение метафора расцветшего сада, воплощающая мирное благоденствие империи. В то же время в портрете Преннера цветочная рама является аксессуаром, оттеняющим красоту модели, как это свойственно французским образцам конца XVII в. Преннер мог оценить декоративный и символический потенциал мотива цветочной рамы, помогая своему дяде Антону Преннеру в подготовке гравированного каталога венской картинной галереи императора Карла VI в поместье Сталлбург, где была целая зала с цветочными натюрмортами и картинами в цветочных обрамлениях. Сколь актуален мотив оказался при дворе российской императрицы, демонстрируют другие виды искусства (триумфальные арки, монументальная живопись, лепное убранство интерьеров, декоративно-прикладное искусство, гравюра).

Ключевые слова: Г.-К. фон Преннер, русское искусство XVIII века, европейское искусство XVIIXVIII веков, живопись, россика, светский портрет в цветочном обрамлении, иконография императрицы Елизаветы Петровны 




III. 12. Georg Kaspar

von Prenner. Portrait

of Empress Elizaveta

Petrovna. 1754. State

Tretyakov gallery,

Moscow, inv. 6249.

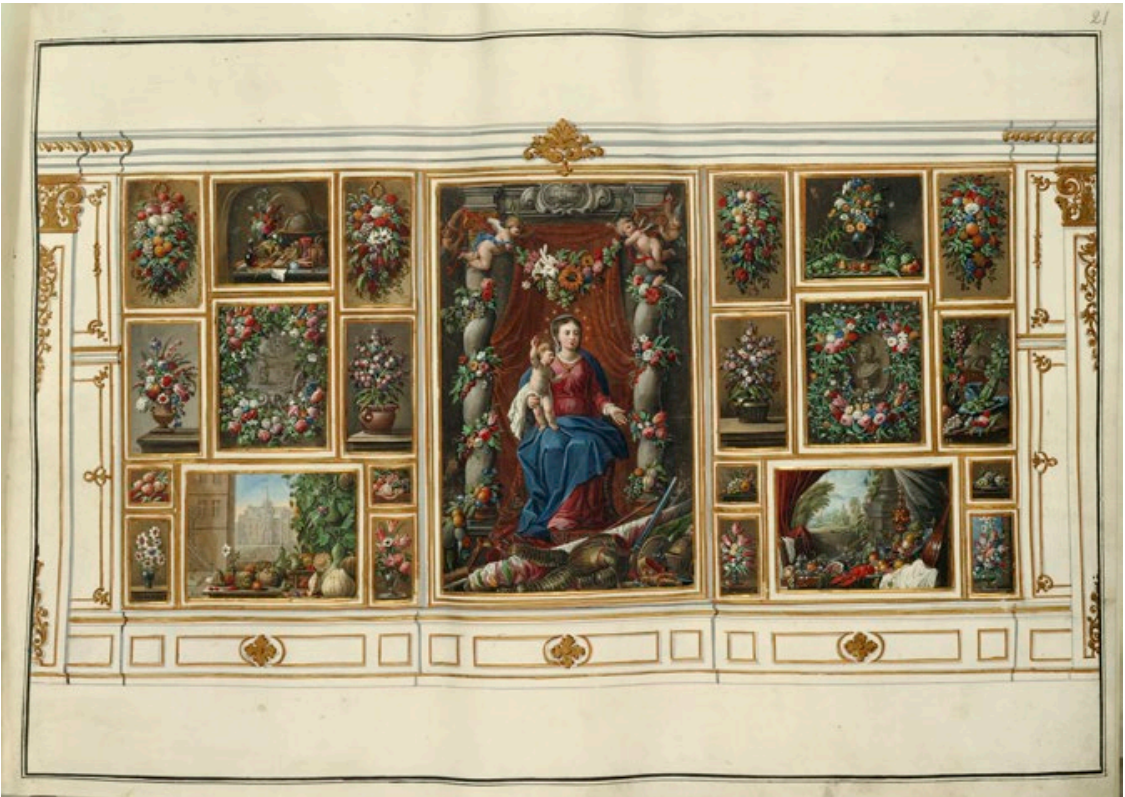

III. 13. Ferdinand à Storffer. Neu eingerichtes Inventarium der Kayl. Bilder Gallerie in der Stallburg welches nach denen Numeris und Maßstab ordiniret und von Ferdinand à Storffer gemahlen worden. Vol. II. 1730.

Kunsthistorisches Museum, Vienna, inv. GG Inventar 


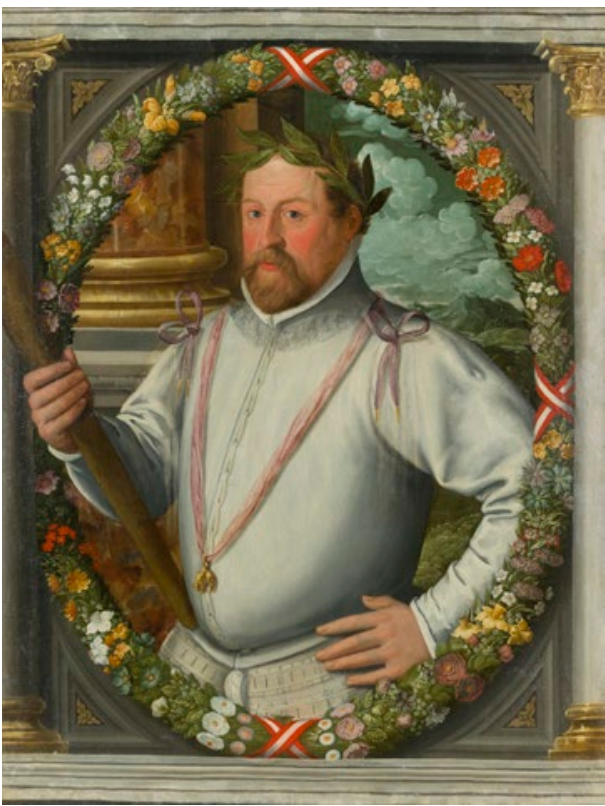

III. 14. Anonym. Portrait of Archduke Ferdinand II, Landesfürst of Tirol. C. 1575. Kunsthistorisches Museum, Vienna, inv. 4501



IIl. 16. Adriaen van der Spelt. Portrait of Kurprinz Karl Emil von Brandenburg. C. 1660. Stiftung Preussische Schlösser und Gärten Berlin-Brandenburg, inv. GK I 30063 / Fotograf: Wolfgang Pfauder

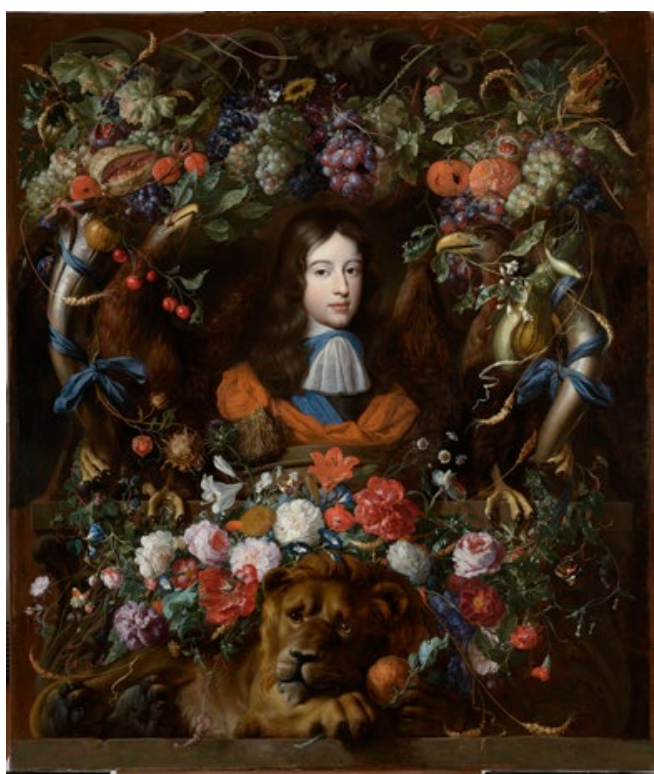

III. 15. Jan Davidsz. de Heem. Portrait of Prince of Orange. C. 1670. Musée des Beaux-Arts de Lyon (C) Lyon MBA — Photo Alain Basset

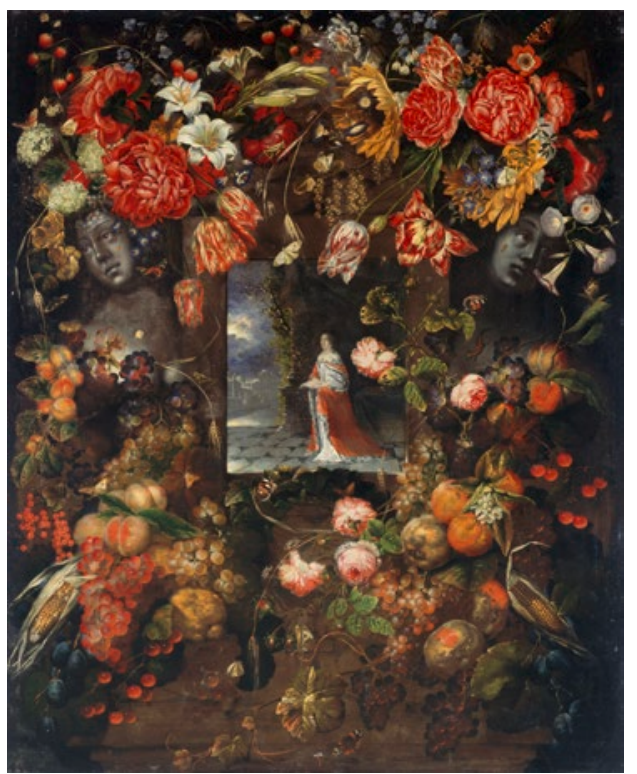

III. 17. Ottomar Elliger <the Older>. Portrait of Kurfürstin Dorothea im Blumen- und Früchtekranz. C. 1670/1675. Stiftung Preussische Schlösser und Gärten Berlin-Brandenburg, inv. GK I 5284 / Fotograf: Gerhard Murza 


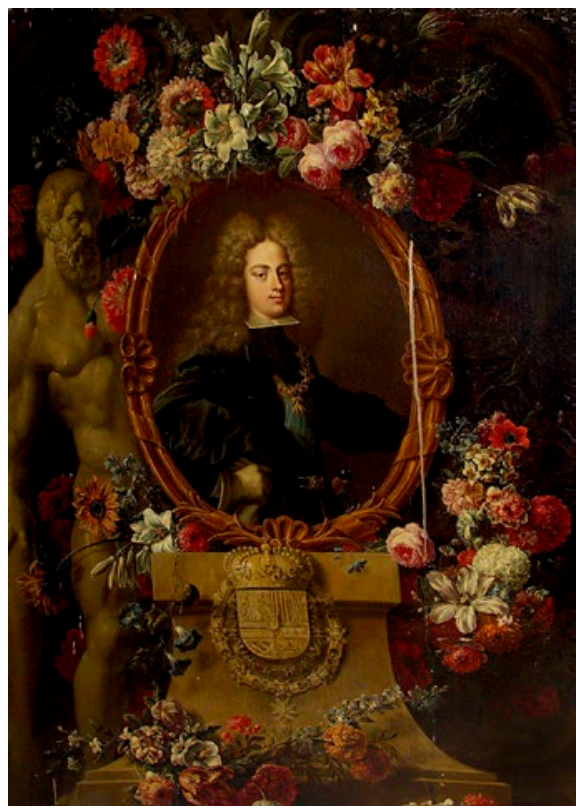

III. 18. Gaspar Peeter Verbruggen the Younger. Frame Decorated with Flowers Surrounding Portrait of Portrait of Philip V of Spain. 1704. Hermitage. № 「Э-4039. @ State Hermitage, Saint-Petersburg, 2020

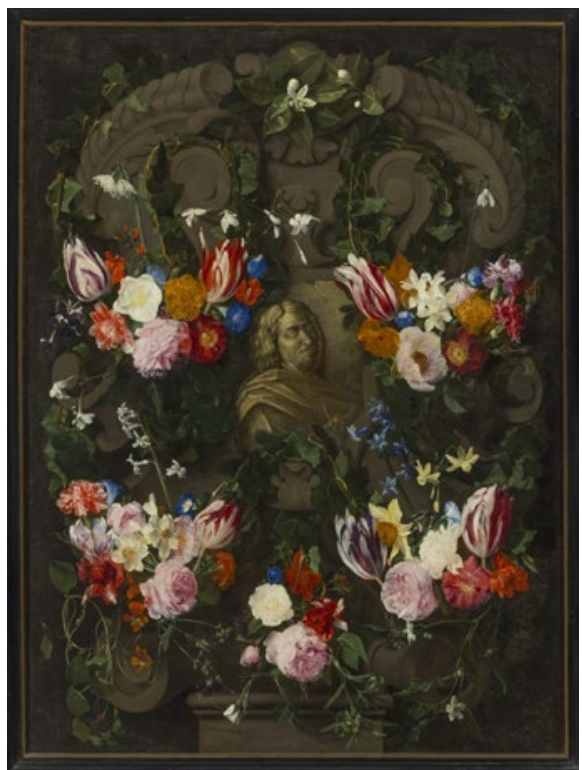

III. 20. Daniel Segers. Portrait of Nicolas Poussin. C. 1650-1651. Muzeum Narodowe w Warszawie, inv. M.0b.566 MNW

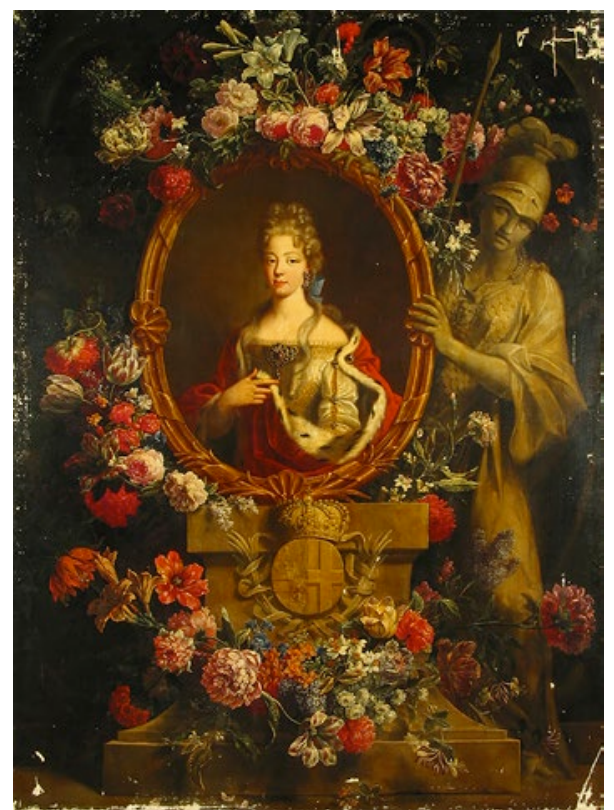

III. 19. Gaspar Peeter Verbruggen the Younger. Frame Decorated with Flowers Surrounding Portrait of Portrait of Maria Luisa of Savoy. 1704. Hermitage. № ГЭ-4038. @ State Hermitage, Saint-Petersburg, 2020

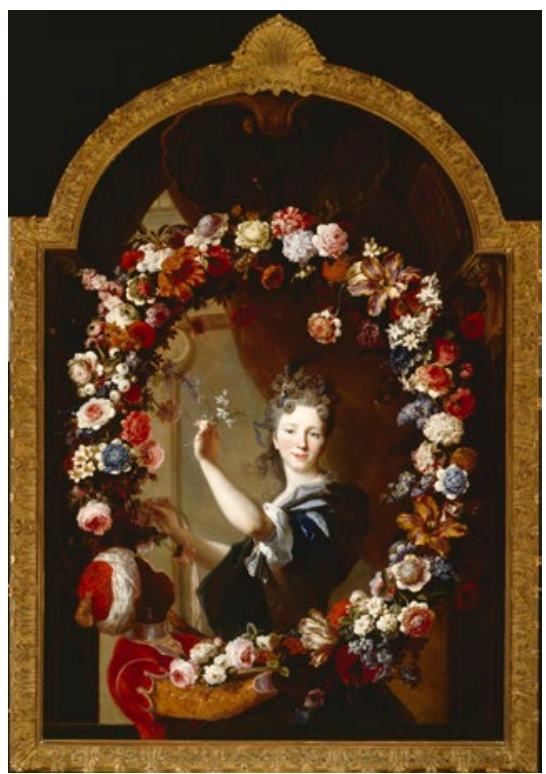

III. 21. Nicolas de Largillière, Jean-Baptiste Belin de Fontenay. Portrait of Hélène Lambert de Thorigny. C. 1696-1700? Honolulu Museum of Arts 